\title{
The Impact of Banking Competition on Economic Growth and Financial Stability: An Empirical Investigation
}

\author{
By George Abuselidze ${ }^{1}$
}

\begin{abstract}
The paper examines the level of competition in banking market using different econometric models and analyzes the impact of efficiency of the banking system on the economic growth of the country. The research discusses to ensure banking competition as a function of the Central Bank. Also, the paper includes some recommendations developed to improve banking competition. Our hypothesis is that the existence of high levels of banking competition and low concentration in the banking market balances the speed of money supply in the economic sector. As a result, the Central Bank's monetary policy will be more effective in achieving its core objectives. Therefore, banking competition contributes to the economic growth of the country. In addition, the monetary policy of the Central Bank concentrates on financial stability, which is one of the fundamental factors in the economic development of a country.
\end{abstract}

Keywords: Monetary Policy, Banks, Competition, Stability, Economic Growth.

\section{Introduction}

The global pandemic has made it clear that one of the most important tasks for the economy of Black Sea Region is to establish a reliable, financially sustainable banking system (Abuselidze and Mamaladze, 2020a; Abuselidze and Slobodianyk, 2021). On the one hand, it is due to the emerging phenomenon of banking institutions as the movement of cash flows in the economy. On the other hand, the institutional and business relations of banks with all subjects of the national economy.

The economy of Georgia is characterized by significant systemic transformations. At the same time, because of specific of their activities banks have been at the centre of many crises, contradictory and hard to predict processes.

It is noteworthy, that the financial support for the real sector of the economy, enterprises and organizations should play an important role in the economic development of the country and the introduction of market principles after the end of the global pandemic. In order for the country to stimulate the supply of money in the real sector of the economy, it is necessary not only to implement complex measures in the field of fiscal policy (Abuselidze, 2020b; 2020d), but also to implement a number of changes in monetary policy (Abuselidze, 2019a; Marcus, 1984). Accordingly, one of the important functions of the Central Bank should be to ensure banking competition. The absence and/or imperfection of the legal framework in this area hinder the banking sector from stimulating the supply 
of money to economic entities and their financial support. In particular, commercial banks are limited by the standards set by major players and the Central Bank provides frequent variability in monetary policy instruments to ensure adequate money supply to the real sector of the economy. This is reason to create risks in terms of price and exchange rate stability. The Central Bank ensures the functioning of the banking system through its legal-normative acts. Therefore, great importance should be attached to the diversification of the functions of the Central Bank. It should be added to the function of ensuring banking competition. The main task should be to manage bank concentration with price stability, which in our opinion will play an important role in regulating money supply.

The aim of the paper is to study the level of competition and concentration in the banking system of Georgia, to substantiate the argument of banking competition as a function of the Central Bank and the importance of its role in economic growth.

\section{Literature Review}

The paper is based on both quantitative and qualitative methods of research. To answer the research question include to analyse the scientific publications on the relevant topic, In particular, the Banking Competition and Bank Concentration and their impact on the socio-economic situation of country (Agostino, et al., 2008; 2010; 2012; Andrieş et al., 2014; Bikker, et al., 2005; Beck, et al., 2013; Berger, et al., 2009; Dash, et al., 2020; DeRamon, et al., 2018; Fu, et al., 2014; Kanas, et al., 2019; Montes, 2014; Shair, et al., 2019; Staikouras, et al., 2006; Tabak, et al., 2012; Tan, et al., 2016; 2017; Titko, et al., 2015; Zigraiova and Havranek, 2016), influence of monetary policy on interbank competition (Abuselidze, 2019b), financial-economic policy (activities) against crisis and fragmentary approaches among them (Abuselidze, 2019c; 2020c). The results of the surveys conducted by the leading research organization, economic models and statistical data (Bank of Georgia, 2019; Canhoto, 2004; Casu and Girardone, 2006; Chalikias, et al., 2020; Claessens and Laeven, 2004; Coccorese, 2008; Delis and Papanikolaou, 2009; Gischer and Stiele, 2009; Hamza, 2011; Liberty Bank, 2019; Leroy, 2019; Maradana, et al., 2017; Mandic, 2014; Marius and Căpraru, 2012; Memić, 2015; Nitsche and Heidhues, 2006; Ou and Tan, 2011; Rezitis, 2010; Ruckes, 2004; Ruzmatovich, 2020; Savel'eva, 2017; Serey, 2015; Sufian, 2011; TBC Bank, 2019; Tera Bank, 2019; VTB Bank, 2019; Wang, 2015; Yildirim and Philippatos, 2007).

According to Marcus (1984), Charletti and Hatmann (2003), strong competition weakens market power, reduces the profit margin and forces banks to take more risks. However, modern literature emerges from the opposite position and investigate that the existence of competition is a guarantee of economic growth and financial stability. In addition, the existence of many data allows scientists to conduct certain types of "tests" for different countries. Based on the use of data from different countries, Shaeck et al (2009; 2012; 2014) and Boyd et al (2005) found empirical evidence that a competitive banking market was less likely to experience bankruptcies and banking crises.

Eyubov (2012) also notes the special role of competition and believes that any country must create equal, competitive conditions for the stability of the banking system.

The research by Jayakumar, et al., (2018) is presented in the paper "Banking competition, banking stability, and economic growth: Are feedback effects at work?". According to the 
research, banking competition plays an important role in the efficient functioning of the banking market and its regulation should be one of the main goals of monetary policy. The present paper reflects the relationship between banking competition, stability and economic growth, which was studied based on data from 32 European countries from 1996-2014. The results of the study show that banking competition, as well as the stability / sustainability of the banking system, is an important long-term driver of economic growth. The results of the study are presented in the following scheme (see Figure 1):
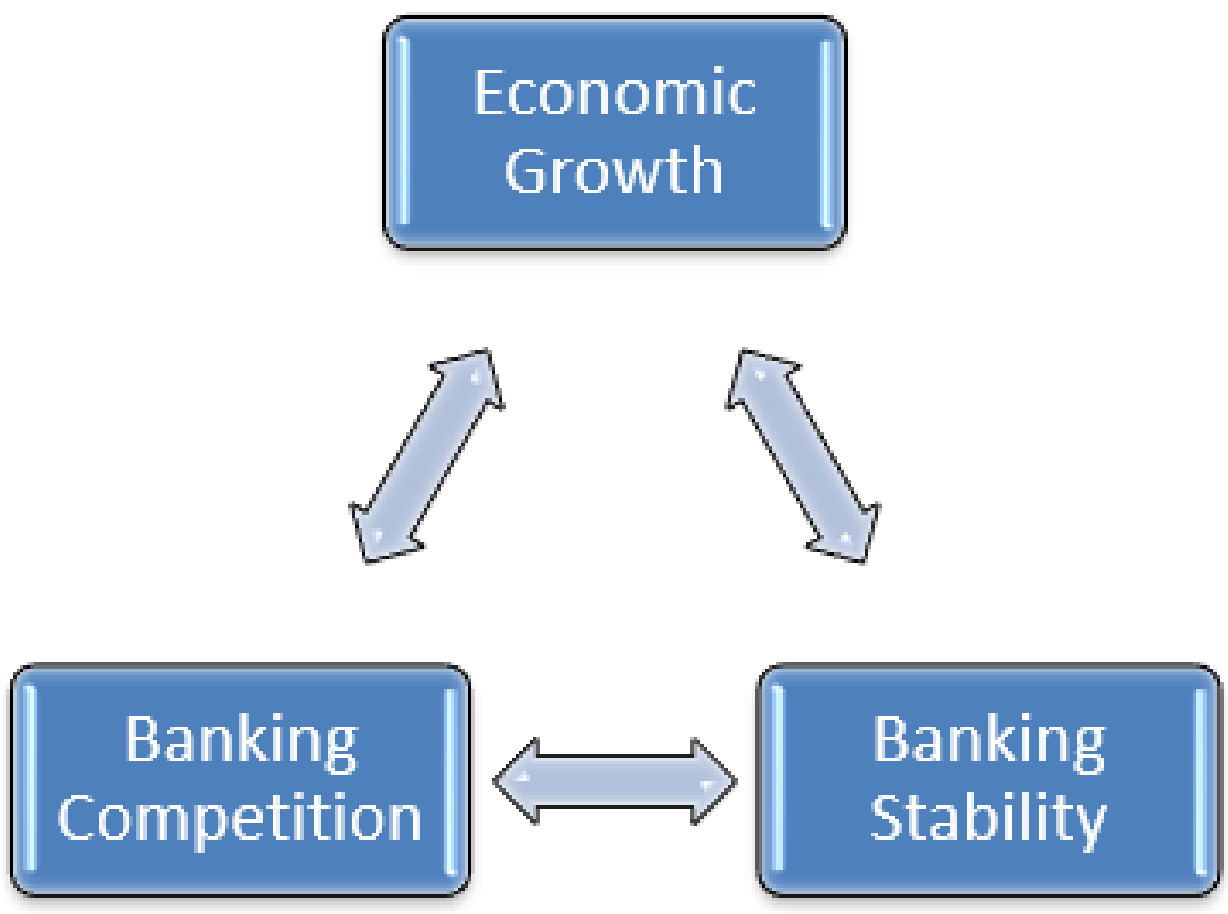

Figure 1: The link between banking competition, stability and economic growth

Source: Compiled by the author based on the data of the Jayakumar, et al., (2018)

The graph shows the possible causal link between banking competition, banking stability and economic growth. Economic growth and development are characterized by negative trends because of a poorly organized banking sector.

Operation of Monetary policy plays the important role in promotion of economic activities and growth of production volume, further socioeconomic development of the country. The monetary policy pursued by the central bank serves two interrelated purposes: to encourage financial system stability and activity of the weakened economic (Abuselidze, 2019a).

Based on the above-presented literature review, I develop the following hypothesis in this article:

H1: Our hypothesis is that the existence of high levels of banking competition and low concentration in the banking market balances the speed of money supply in the economic sector. 


\section{Materials and Methods}

Structural rather than structural models are used to define and/or determine the level of banking competition in a country. According to the structural model, we can be determined the share of individual banks in the total assets of the banking sector, measure to market share and concentration coefficient. And non-structural models consider competition based on the mechanism of determining prices and marginal value in the banking market. In particular,

The concentration index is considered to be the most common method of assessing competition and to determine the share of large banks in the banking market (Stazhkova, et al., 2017).

$C R_{k}=\sum_{j=1}^{k} q$,

Where:

$\mathrm{CR}$ - $\mathrm{k}$ - concentration index;

$\mathrm{q}$ - The bank's share in the region.

The index is calculated with the participation of three or four largest banks, depending on which the index will be compiled with the participation of three or four banks. In the case of three banks, if the index rate is less than $45 \%$, the market is considered concentrated, from $45 \%$ to $70 \%$ - deadly concentrated, at a rate higher than $70 \%$ the market is considered highly concentrated.

The Index Linda (1976) is used to determine the level of inequality between banks operating in the banking sector:

$I L_{K}=\frac{K}{k+(k+1)} \sum_{i=1}^{k} M i$

Where:

IL $\mathrm{K}_{\mathrm{K}}$ - Index Linda;

$\mathrm{K}$ - is the $\mathrm{K}$ group of the largest banks in the banking sector;

$\mathrm{Mi}$ - is the ratio of the average relative share of the largest number of economic agents of the largest number of $I$ in the relevant market segment $(K-i)$ to the total market share of the largest number of economic agents;

$\mathrm{i}$-is the identifier of a specific authorized person. The value of the index $\mathrm{i}$ varies from 1 to $\mathrm{k}$.

The non-structural model includes the Lerner index (monopoly power index) (Lerner, 1934), which is calculated as follows:

$L=\frac{\mathrm{P}-\mathrm{MC}}{\mathrm{P}}$,

Where:

$\mathrm{L}$ - is the Lerner index;

$\mathrm{MC}$ - marginal costs;

$\mathrm{P}$ - monopolistic price. In the case of pure monopoly, the Lerner index is equal to one.

The Lerner index practically shows the monopoly price set on the value of credit. This index represents the difference between the weighted average price of the oligopoly price and the bank's marginal costs. The value of the Lerner index can range from 0 (perfect competition) to 1 (monopoly).

According to the Competition Law of Georgia (2012), the definition of "market 
monopolization" has been replaced by the concept of "market concentration". So, a structural model - Herfindahl-Hirschmann Index (HHI) ${ }^{1}$ (Oliver and Hirschman, 1946; Weinstock, 1982; Werden, 1998), is used to assess the level of competition according to market structure indicators. An increase in the index score means a decrease in competition and an increase in market power, while a decrease in the index score indicates a reverse process.

$H H I=\sum_{j=1}^{N} K_{j}^{2}$,

Where: $K_{j}^{2}$ - is the share of the i-yur bank in the market, it is calculated as follows:

$K_{j}=\sum_{i=1}^{n} \frac{V_{j}}{V_{m}}$,

Where: $V_{j}$ is the sales volume of the bank's product and $V_{m}-$ is the total volume of the banking market.

\section{Results and Discussion}

One of the main goals of any central bank is to promote the growth of the overall national product. One of the factors influencing the development of the economy is the lack of competition. Several studies show that there is not any exact answer as to how much competition can be a guarantee of economic growth in the banking sector. In our opinion, it is noteworthy that the competition is important factor to increase the real economy for many reasons. As in many other businesses, competition in the banking sector can have a significant impact on the efficiency of financial services production, the quality of financial products, the quality of innovation in the existing sector and so on.

It is well known that competition is a positive phenomenon for many industries. Its effect can also be positively assessed in terms of the functioning of the banking sector. Financial markets and the banking sector play an important role in the efficient functioning and development of the economy.

Competition Law of Georgia (2012) includes competition in banking sector and other various fields. According to the methodology of Competition Agency of Georgia, the levels of market concentration based on the Herfindahl-Hirschman index (score) are defined as follows:

Low concentrated $-H H I<1250$

Average concentrated $-1250<H H I>2250$

Highly concentrated - $H H I>2250$.

Since 2014, the banking sector in Georgia has been characterized by a process of consolidation - the unit of various banks and the constant growth of the banking portfolio of the leading banks in the banking sector. In 2000-2019, consolidation takes the following form (see Figure 2).

${ }^{1}$ An economic concept that is widely used in competition law, antitrust and technology management. 


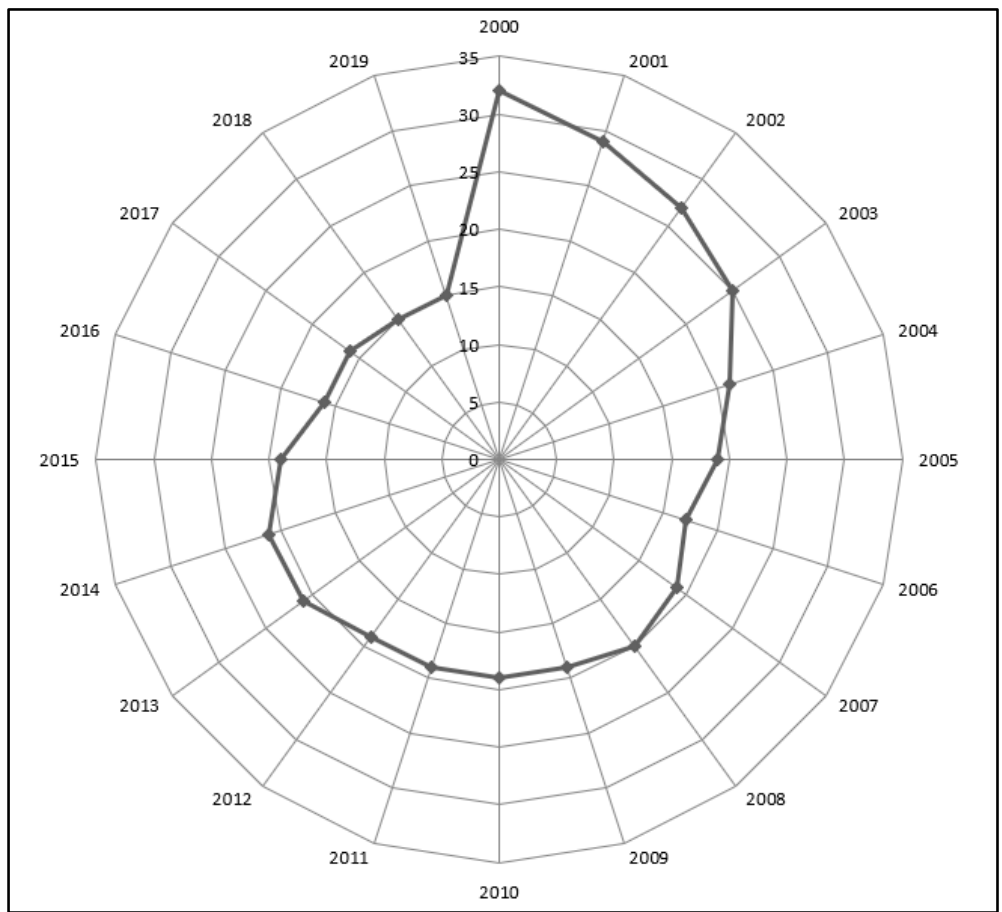

Figure 2: Commercial Banks

Source: Statistics of the banking sector officially published by the National Bank of Georgia

According to the given methodology, the concentration of the banking market was studied based the data of 2016-2018:

Table 1: HHI Index by Total Assets Method 2016-2018.

\begin{tabular}{|l|c|c|c|c|c|c|}
\hline & \multicolumn{2}{|c|}{2016} & \multicolumn{2}{c|}{2017} & \multicolumn{2}{c|}{2018} \\
\hline Commercial Banks & \multicolumn{2}{|c|}{ Total assets method } & \multicolumn{2}{c|}{ Total assets method } & \multicolumn{2}{c|}{ Total assets method } \\
\hline & $\mathrm{Kj}$ & $\mathrm{Kj}^{\wedge} 2$ & $\mathrm{Kj}$ & $\mathrm{Kj}^{\wedge} 2$ & $\mathrm{Kj}$ & $\mathrm{Kj}^{\wedge} 2$ \\
\hline Bank of Georgia & $34,68 \%$ & 1202.7584 & $35,40 \%$ & 1252.854248 & $37,15 \%$ & 1380.489282 \\
\hline TBC Bank & $34,67 \%$ & 1201.854103 & $36,28 \%$ & 1316.475929 & $39,53 \%$ & 1562.804248 \\
\hline VTB Bank of Georgia & $4,98 \%$ & 24.80344875 & $4,38 \%$ & 19.21360056 & $4,22 \%$ & 17.79626138 \\
\hline Procredit Bank & $4,49 \%$ & 20.19052966 & $3,79 \%$ & 14.39456259 & $3,83 \%$ & 14.70398378 \\
\hline Basis Bank & $3,03 \%$ & 9.1724635 & $3,45 \%$ & 11.93084955 & $3,67 \%$ & 13.49170822 \\
\hline Liberty Bank & $5,20 \%$ & 27.00223617 & $5,08 \%$ & 25.7591927 & $0,00 \%$ & 2.21631 \\
\hline Kartu Bank & $4,58 \%$ & 20.9355284 & $3,65 \%$ & 13.33670634 & $3,10 \%$ & 9.637426242 \\
\hline Silk Road Bank & $0,26 \%$ & 0.0663169 & $0,16 \%$ & 0.026979787 & $0,19 \%$ & 0.037721585 \\
\hline Credo Bank & $1,75 \%$ & 3.0709097 & $1,72 \%$ & 2.971992325 & $1,99 \%$ & 3.9473569 \\
\hline Finca Bank Georgia & $0,89 \%$ & 0.800192761 & $0,83 \%$ & 0.686149979 & $0,76 \%$ & 0.577333776 \\
\hline Halyk Bank Georgia & $1,21 \%$ & 1.469813 & $1,20 \%$ & 1.43857283 & $1,25 \%$ & 1.574348361 \\
\hline Isbank Georgia & $0,89 \%$ & 0.790789 & $0,67 \%$ & 0.44394623 & $0,68 \%$ & 0.458757779 \\
\hline TeraBank & $2,24 \%$ & 5.036189 & $2,35 \%$ & 5.533484065 & $2,47 \%$ & 6.118869516 \\
\hline Ziraat Bank Georgia & $0,22 \%$ & 0.04707648 & $0,26 \%$ & 0.068973353 & $0,29 \%$ & 0.0865524346 \\
\hline Total, HHI & $\mathrm{HHI}=2518.82618183986$ & $\mathrm{HHI}=2665.72054709869$ & $\mathrm{HHI}=301242.390933687$ \\
\hline
\end{tabular}

Source: Based on the data of the National Bank of Georgia compiled by the author 
As the results of the research show, the HHI index is characterized by an upward trend. The figure for 2018 is 119.6 times higher than the same period in 2016, which shows that the concentration in the banking sector is increasing. All three years belong to the third group of the HHI category and far exceed the lower limit set for this group.

At the same time, it is clear that only two leading banks (Bank of Georgia and TBC Bank) are responsible for the current situation. The market share of these banks is characterized by an upward trend. The Bank of Georgia had a 34.68\% share of total bank assets in 2016, up from $37.15 \%$ in 2018 . The growth rate is much higher in the case of TBC Bank, which in 2016 was characterized by an equal rate of the same size as the Bank of Georgia (34.67\%) and this amount increased to 2018 and amounted to $39.53 \%$.

We also used the HHI method to estimate the level of concentration in the banking sector according to net loans, the results of which look as follows: (see Table 2).

Table 2: HHI Index by Net Borrowing Method 2016-2018

\begin{tabular}{|c|c|c|c|c|c|c|}
\hline \multirow{3}{*}{ Commercial Banks } & \multicolumn{2}{|c|}{2016} & \multicolumn{2}{|c|}{2017} & \multicolumn{2}{|r|}{2018} \\
\hline & \multicolumn{2}{|c|}{ Net borrowing method } & \multicolumn{2}{|c|}{ Net borrowing method } & \multicolumn{2}{|c|}{ Net borrowing method } \\
\hline & $\mathrm{Kj}$ & $\mathrm{Kj}^{\wedge} 2$ & $\mathrm{Kj}$ & $\mathrm{Kj}^{\wedge} 2$ & $\mathrm{Kj}$ & $\mathrm{Kj}^{\wedge} 2$ \\
\hline Bank of Georgia & $33,52 \%$ & 1123.306192 & $34,10 \%$ & 1162.882992 & $34,66 \%$ & 1201.112504 \\
\hline TBC Bank & $37,48 \%$ & 1404.402155 & $38,13 \%$ & 1453.933346 & $38,14 \%$ & 1454.935037 \\
\hline VTB Bank of Georgia & $4,91 \%$ & 24.06222664 & $4,35 \%$ & 18.95053581 & $4,17 \%$ & 17.38178498 \\
\hline Procredit Bank & $4,50 \%$ & 20.23193257 & $4,52 \%$ & 20.44890268 & $3,89 \%$ & 15.11745585 \\
\hline Basis Bank & $3,12 \%$ & 9.746685303 & $3,47 \%$ & 12.04850604 & $3,42 \%$ & 11.71574086 \\
\hline Liberty Bank & $3,32 \%$ & 11.00479955 & $3,47 \%$ & 12.02279718 & $3,62 \%$ & 13.12778891 \\
\hline Kartu Bank & $4,49 \%$ & 20.14285414 & $3,64 \%$ & 13.25405839 & $3,12 \%$ & 9.753102446 \\
\hline Silk Road Bank & $0,04 \%$ & 0.001845677 & $0,03 \%$ & 0.000868093 & $0,06 \%$ & 0.00369015 \\
\hline Credo Bank & $2,33 \%$ & 5.426374274 & $2,36 \%$ & 5.552255249 & $2,58 \%$ & 6.671132968 \\
\hline Finca Bank Georgia & $1,06 \%$ & 1.127445804 & $1,01 \%$ & 1.028403365 & $0,83 \%$ & 0.68506047 \\
\hline Halyk Bank Georgia & $1,44 \%$ & 2.064331301 & $1,49 \%$ & 2.235023328 & $1,52 \%$ & 2.3227151 \\
\hline Isbank Georgia & $0,94 \%$ & 0.892017348 & $0,72 \%$ & 0.517083426 & $0,59 \%$ & 0.353490564 \\
\hline TeraBank & $2,28 \%$ & 5.220670116 & $2,56 \%$ & 6.576961078 & $2,54 \%$ & 6.429710327 \\
\hline Ziraat Bank Georgia & $0,08 \%$ & 0.006128052 & $0,08 \%$ & 0.006734486 & $0,13 \%$ & 0.01687768 \\
\hline Total, HHI & \multicolumn{2}{|c|}{$\mathrm{HHI}=2627.885193$} & \multicolumn{2}{|c|}{$\mathrm{HHI}=2709.461328$} & \multicolumn{2}{|c|}{$\mathrm{HHI}=2740.14093$} \\
\hline
\end{tabular}

Source: Based on the data of the National Bank of Georgia compiled by the author

According to this method, the banking sector of Georgia is characterized by high concentration (monopolization). In 2016-2018, the size of HHI is on an upward trend, although the growth rate is low compared to the assets method.

In order to calculate the level of competition in the concentration index, we were guided by the total asset method of the HHI index and determined the market share of two, three and five leading banks in the Georgian banking sector. The results of the concentration index are as follows:

$$
\begin{aligned}
C R 2 & =\sum_{j=1}^{k=2} q=K_{1} \%+K_{2} \%, \\
C R 3 & =\sum_{j=1}^{k=3} q=K_{1} \%+K_{2} \%+K_{3} \%, \\
C R 5 & =\sum_{j=1}^{k=5} q=K_{1} \%+K_{2} \%+\cdots+K_{5} \%,
\end{aligned}
$$

As we can see from the concentration index, the Georgian banking sector is characterized by high concentration not only in the case of shares of two banks, but also only in the case 
three or five banks. The index shows that two leading banks in the market hold about $77 \%$ of the total market share, $81 \%$ - three banks, and in the case of five banks this rate exceeds $88 \%$ (see Figure 3).

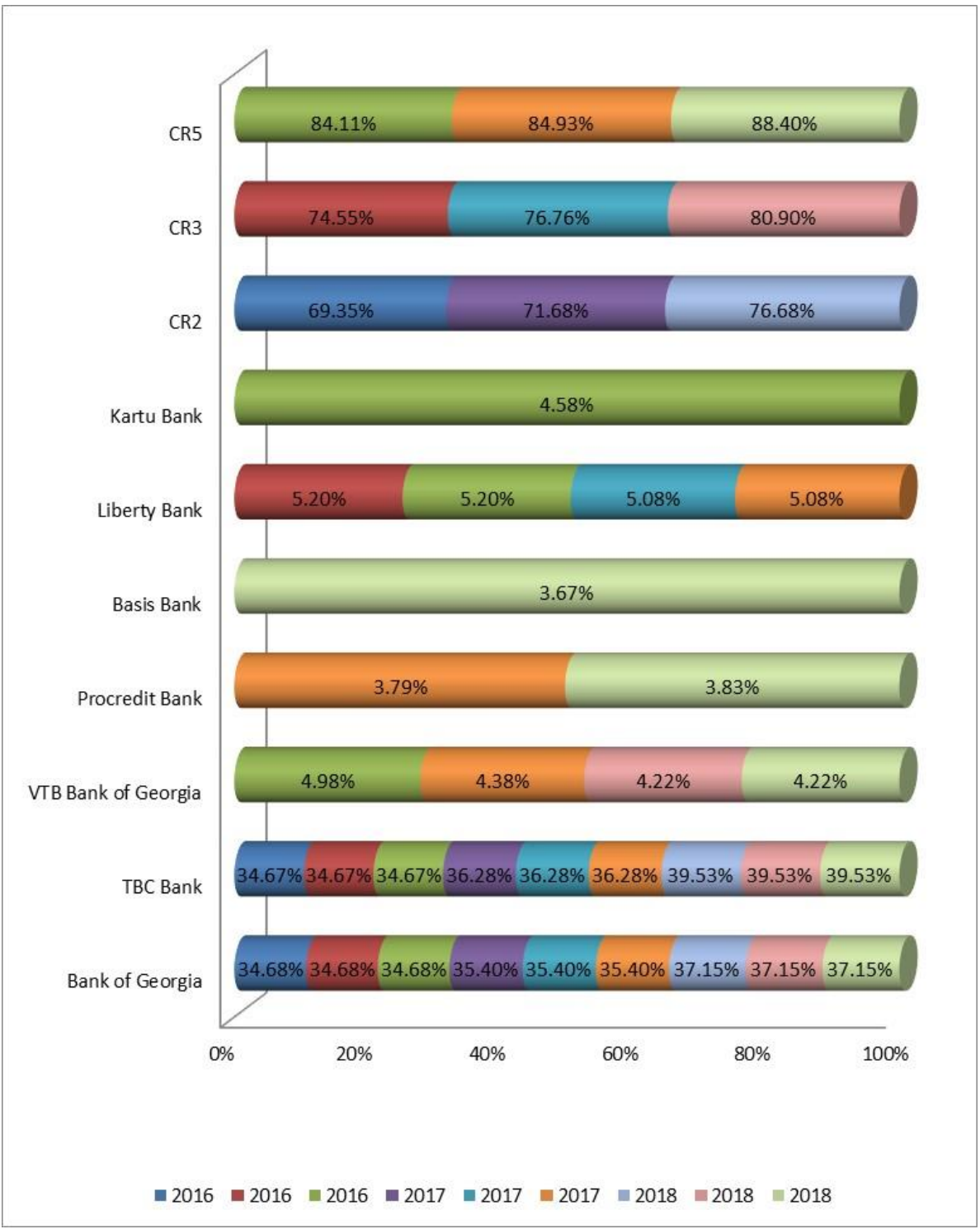

Figure 3: Concentration of the banking market

Source: Based on the data of the National Bank of Georgia compiled by the author

We also used non-structural indicators to assess the degree of concentration of the banking sector. In particular, we have calculated the Linda index for the two, three and five largest banks.

For the two largest banks the Linda index is equal to: 
$I L_{K}=\frac{1}{2}\left[\left(\frac{K_{1}}{\left(K_{2}+K_{3}\right) / 2}\right)+\left(\frac{\left(K_{1}+K_{2}\right) / 2}{K_{3}}\right)\right] \times 100 \%$

For the three largest banks the Linda index is equal to:

$I L_{K}=\frac{1}{3}\left[\left(\frac{K_{1}}{\left(K_{2}+K_{3}+K_{4}\right) / 3}\right)+\left(\frac{\left(K_{1}+K_{2}\right) / 2}{\left(K_{3}+K_{4}\right) / 2}\right)+\left(\frac{\left(K_{1}+K_{2}+K_{3}\right) / 3}{K_{4}}\right)\right] \times 100 \%$

For the five largest banks the Linda index is equal to:

$I L_{K}=\frac{1}{5}\left[\left(\frac{K_{1}}{\left(K_{2}+K_{3}+K_{4}+K_{5}+K_{6}\right) / 5}\right)+\left(\frac{\left(K_{1}+K_{2}\right) / 2}{\left(K_{3}+K_{4}\right) / 2}\right)+\left(\frac{\left(K_{1}+K_{2}+K_{3}\right) / 3}{\left(K_{4}+K_{5}\right) / 3}\right)+\left(\frac{\left(K_{1}+K_{2}+K_{3}+K_{4}\right) / 4}{\left(K_{4}+K_{5}\right) / 4}\right)+\right.$ $\left.\left(\frac{\left(K_{1}+K_{2}+K_{3}+K_{4}+K_{5}\right) / 5}{K_{6}}\right)\right] \times 100 \%$

As the Linda index increases with the addition of new banks, we can conclude that the Georgian banking sector is characterized by high concentration (see Figure 4).

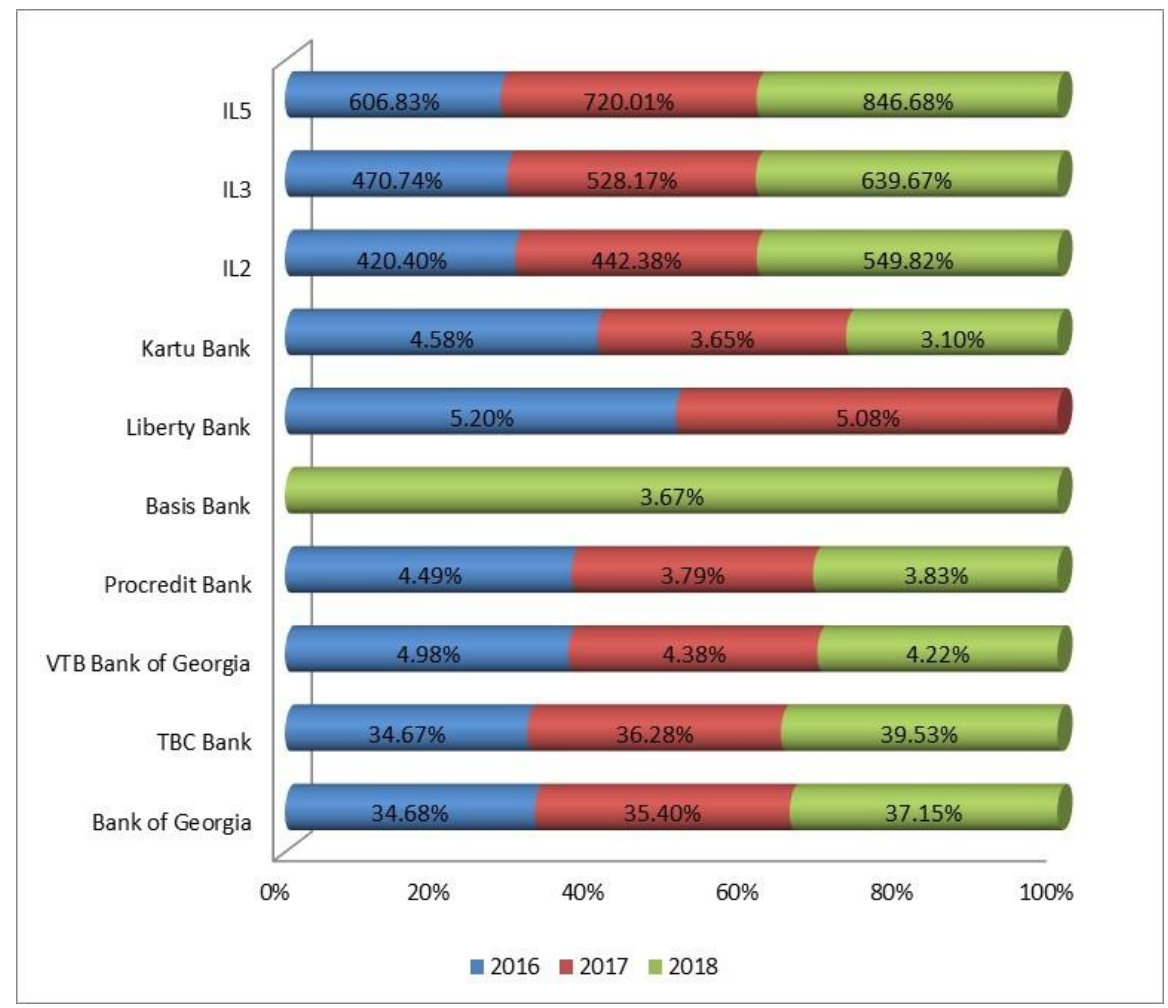

Figure 4.

Source: Based on the data of the National Bank of Georgia compiled by the author

The Lerner index makes it possible to measure the degree of impact of a change in factor prices on a change in a bank's income. We performed an econometric assessment of the elasticity of percentage and non-percentage of the bank according to the following three factors: Average Funding Rate (AFR), Price of Other Non Interest and Labor Expense (PONILE), Price of Personnel Expense (PPE). The H-statistic index is calculated by summing the obtained elasticity, the higher the revenue elasticity, the more competitive the banking market. However, $\mathrm{H} 1$ is the link between interest costs and (own equity minus assets), H2 is the relationship between staff costs and bank capital, H3 is the ratio of net 
non-interest income to own equity (see Figure 5).

$$
H_{\text {statistic }}=\beta_{A F R}+\beta_{\text {PONILE }}+\beta_{P P E}=\left\{\begin{aligned}
H_{\text {statistic }} & =0 \rightarrow \text { Monopoly } \\
0<H_{\text {statistic }}<1 & \rightarrow \text { Monopolistic Competition } \\
H_{\text {statistic }} \geq 1 & \rightarrow \text { Perfect Competition }
\end{aligned}\right.
$$

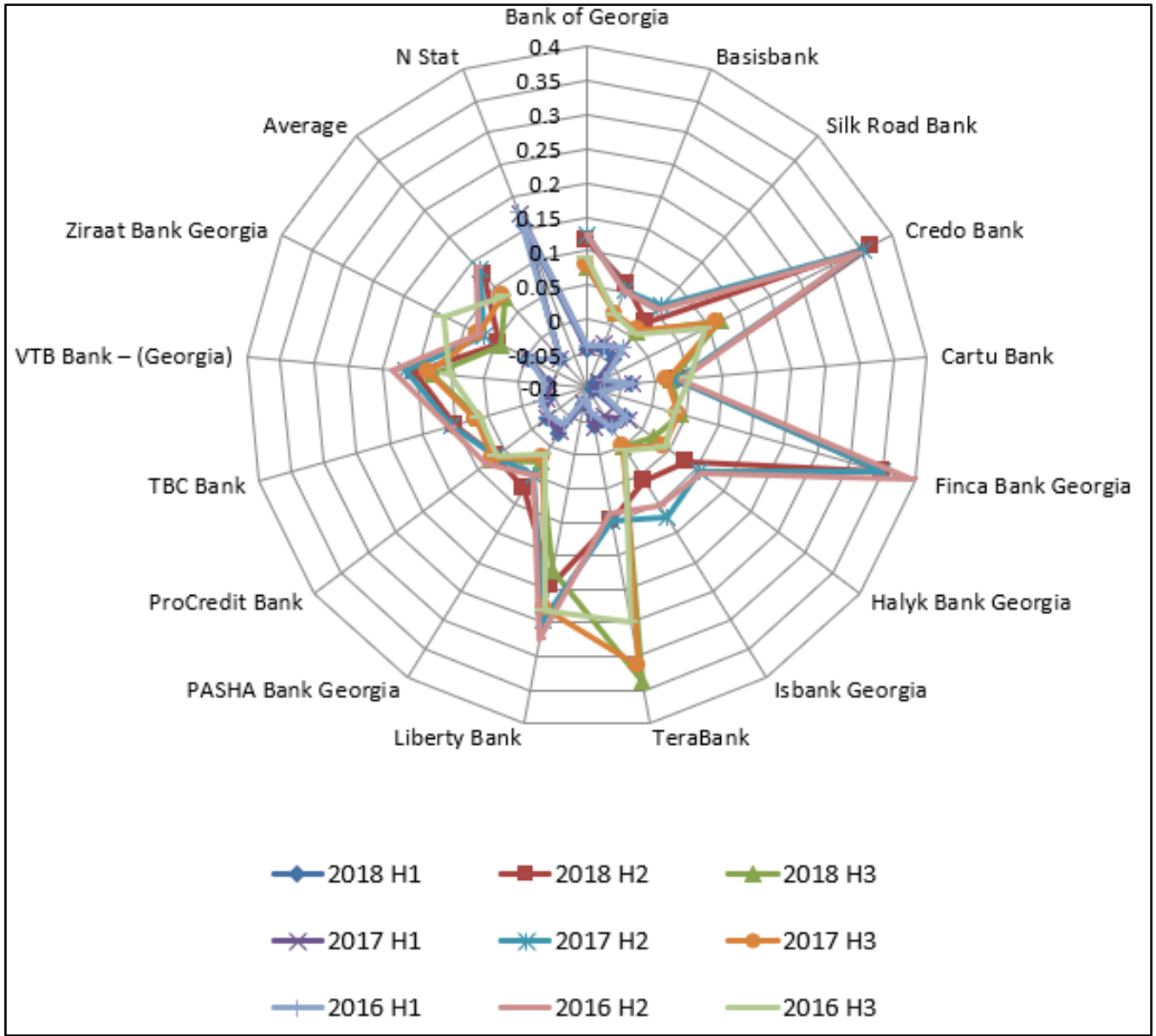

Figure 5: H-statistic index of Georgia 2016-2018

Source: Based on the data of the National Bank of Georgia compiled by the author

The banking system plays an important role in the economy. It promotes the redistribution of financial resources between sectors of the economy and contributes the efficient allocation of financial resources to promote economic growth and development (see Figure 6). 


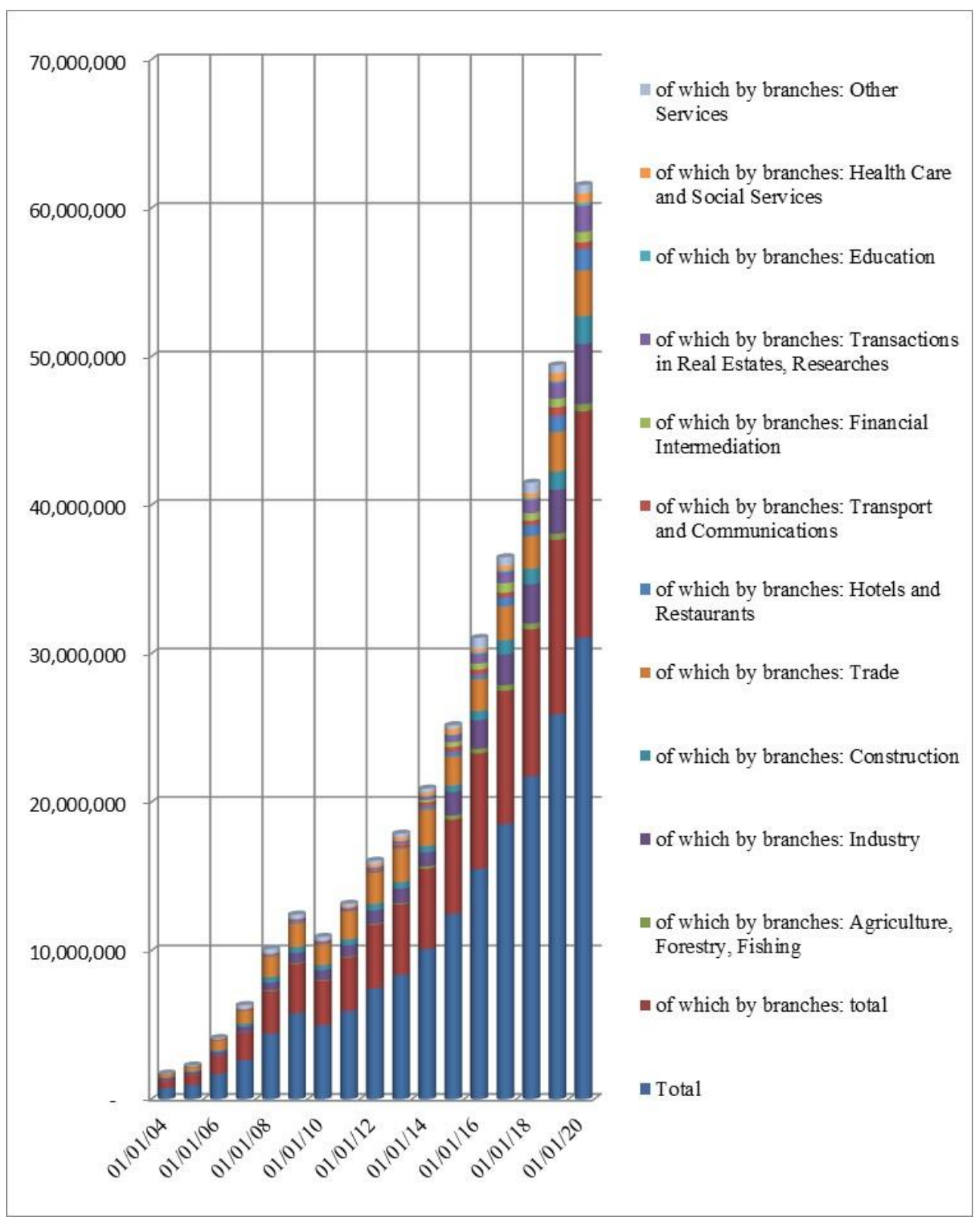

Figure 6: Loans to the National Economy

Source: Based on the data of the National Bank of Georgia compiled by the author

An important role of competition in the economy sector can be defined by the following six reasons: First, the relevant level (quality) of financial services to consumers in the market; Second, to promote the efficient functioning of the financial sector; Third, the stability of financial systems; Fourth, effective management of financial operations (management); Fifth, improve monetary policy through interbank market rates and in 
general, promote industrial and economic growth.

Financial stability is a situation in which a banking system consisting of financial intermediaries, markets and market infrastructure will be able to withstand shock and financial imbalances (Figure 7).

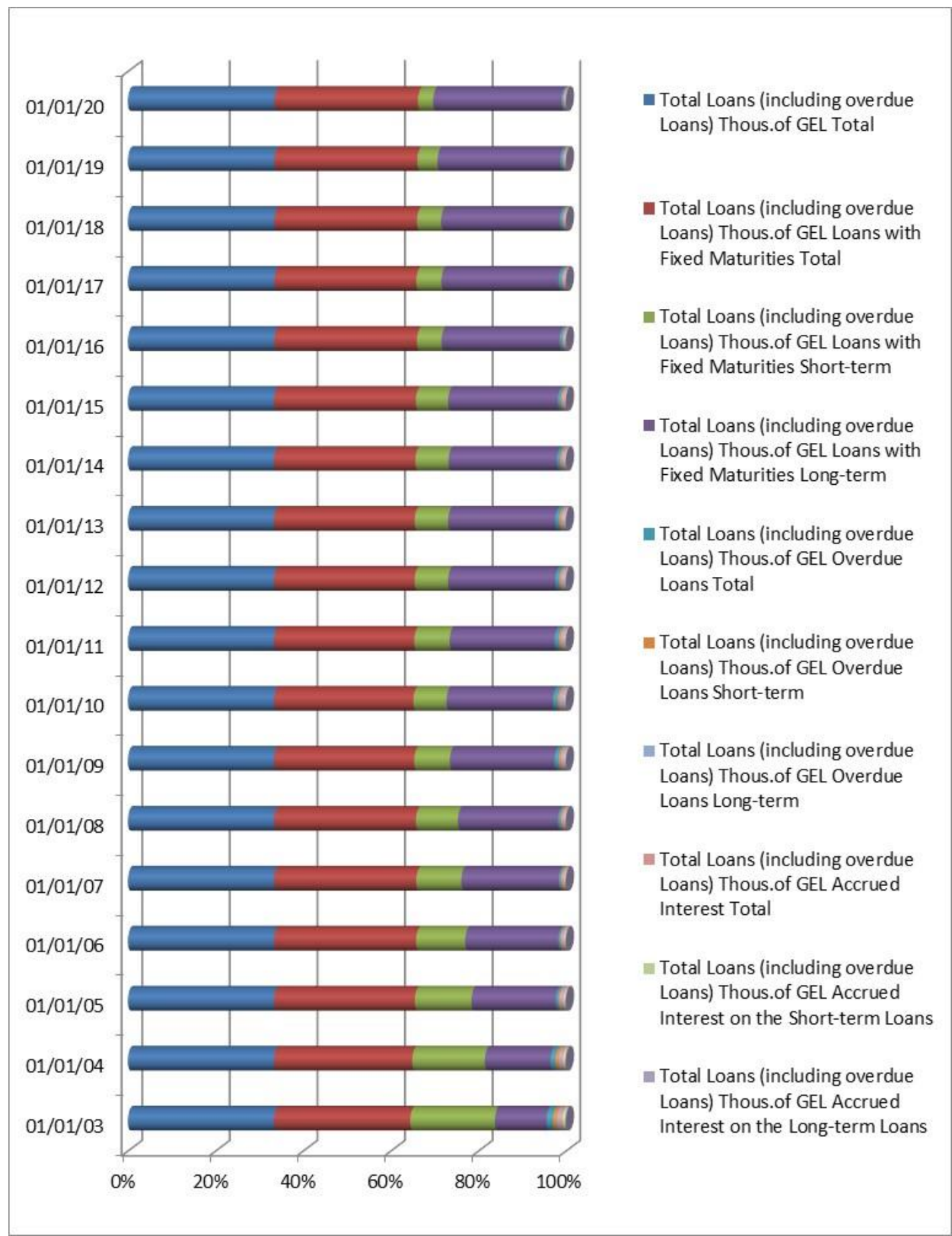

Figure 7: Total Loans (including overdue Loans) Thous. Of GEL

Source: Based on the data of the National Bank of Georgia compiled by the author 
In order to develop banking competition, it is necessary to achieve a reduction in bank concentration, which in turn leads to financial stability and makes it possible to reduce the likelihood of delays in the process of financial intermediation. Financial stability is a very important factor for the banking sector, which allows it to carry out financial processes, promotes the movement of cash flows between creditors and debtors, and plays an important role in the efficient distribution of financial resources. These factors contribute to economic growth and development. In contrast, financial instability threatens these aspects of the economy and may affect other sectors as well. The results of the study are presented in the following scheme (see Figure 8).

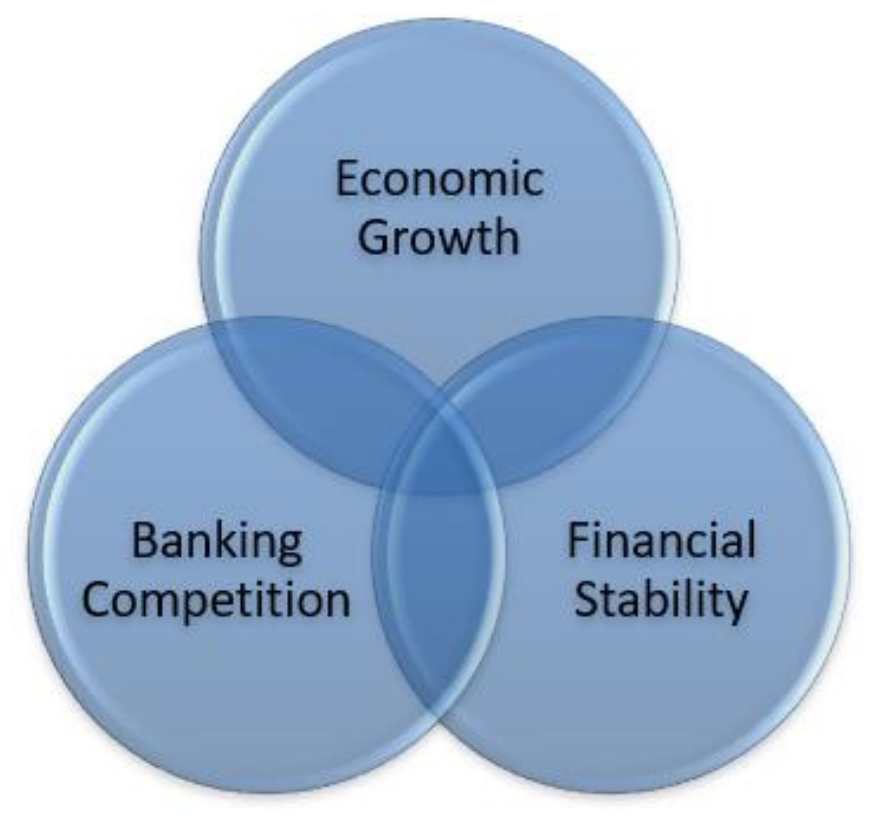

Figure 8 .

A strong banking sector is a prior condition for the sustainable development of country's economy. The competitive banking sector promotes the liquidity of the economy, which leads to the accumulation of capital, economic growth and employment. Capital is the driver of sustainable economic growth. Capital formation and accumulation should be a key element of any strategy for economic growth. A competitive and diverse banking system is associated with a low-risk loan portfolio. A bank can develop a business and encourage entrepreneurship in the country. In a highly competitive environment, financial institutions reduce interest rates to attract customers and diversify their banking product, which has a positive impact on financial sustainability. Commercial banks are a means of promoting investment activity through loans, which contributes to the growth of the country's economy.

The quality of financial institutions, regulation and the quality of regulatory institutions, market refinement and competition significantly improve the efficiency of capital investment and reduce the risks associated with different financing options. To improve 
competition, regulatory institutions need to focus on creating appropriate incentive frameworks. These frameworks should include rules for entering and exiting the market, precautionary principles and oversight. In times of crisis, corrective action, restructuring measures should be used, which should ultimately help reduce potential moral hazard problems and avoid risk overruns, as well as reduce fiscal costs for taxpayers. The market capitalization requirements, as well as greater transparency in operations and prices, are types of actions that will improve oversight to improve competition. In contrast, rising regulatory spending, which raises barriers to entry into the financial sector, deprives countries of many of the benefits of an efficient and innovative banking system and also violates competition in the marketplace.

The quality of competition is an important aspect of the functioning of the banking sector. Therefore the financially dependent external sectors are growing faster in a competitive banking system. On the other hand, the development of the banking sector is a result of economic growth. The faster the Real National Income and / or Gross National Product growth rate, the greater the demand for banking and / or financial intermediation. Consequently, the quality of competition in the banking sector affects the availability of financial services and external financing.

The link between banking competition and sustainability affects resource availability, choice, and economic stability. A competitive banking system improves the quality of credit access for banks. It could lead to an improvement in the banks 'loan portfolio, which ultimately contributes to the efficient allocation of resources. Maintaining competition at a certain level contributes to the sustainability and stability of the banking sector by minimizing risks, stimulating the loan market and monitoring system.

\section{Conclusion}

Based on economic research, it is proven that the sustainability of the banking sector stimulates economic growth in the long run. In turn, as a result of the increase in banking stability, the quality of competition in the banking sector is increasing. The banking sector is highly competitive in countries where the level of transparency in the banking sector is stimulated. At the same time, banking competition and banking stability strengthen each other. In addition to the positive impact of stability on banking competition, on the contrary, banking stability can also help strengthen competition. The stability of the banking system can lead to a well-organized investment in funds. In turn, effective investment contributes to further growth of savings, which can increase banking competition.

Since banks play a fundamental role in financing the economy, banking competition affects the development of the economy. It is expected that a higher degree of competition in the banking market will ensure prosperity by reducing the cost of financial services and thus accelerating investment activity. This effect is due to two circumstances. On the one hand, higher levels of banking competition should lead to lower levels of monopolistic power in banks and consequently, lower bank prices. In turn, increased competition should help banks reduce their costs, which will have a positive impact on their operations. Thus, it is fundamental to have a sustainable, stable and efficient banking system to facilitate the efficient allocation of resources and risks throughout the economy. 


\section{References}

Abuselidze, G. (2019a). Modern Challenges of Monetary Policy Strategies: Inflation and Devaluation Influence on Economic Development of the Country. Academy of Strategic Management Journal. 18(4), 1-10.

Abuselidze, G., and Kizinidze, M. (2019b). Influence of central bank regulations on interbank competition in association with EU. E3S Web of Conferences. 135, 04037. DOI: https://doi.org/10.1051/e3sconf/201913504037

Abuselidze, G. (2019c). European Integration of Georgia and Financial-Economic Condition: Achievements and Challenges. European Journal of Sustainable Development. 8(1), 53-68. DOI: https://doi.org/10.14207/ejsd.2019.v8n1p53

Abuselidze, G., and Mamaladze, L. (2020a). The Impact of the COVID-19 Outbreak on the Socio-Economic Issues of the Black Sea Region Countries. Computational Science and Its Applications - ICCSA 2020. Lecture Notes in Computer Science, 12253. Springer, Cham. DOI: https://doi.org/10.1007/978-3030-58814-4_32

Abuselidze, G. (2020b). Optimality of Tax Policy on the Basis of Comparative Analysis of Income Taxation. European Journal of Sustainable Development. 9(1), 272-293. DOI: https://doi.org/10.14207/ejsd.2020.v9n1p272

Abuselidze, G., and Gogitidze, I. (2020c). Tax policy for business entities under the conditions of association with the European Union: features and optimization directions. E3S Web of Conferences. 166, 13013. DOI: https://doi.org/10.1051/e3sconf/202016613013

Abuselidze, G., and Mamuladze, L. (2020d). The Peculiarities of the Budgetary Policy of Georgia and the Directions of Improvement in Association with EU. SHS Web of Conferences. 73, 01001. DOI: https://doi.org/10.1051/shsconf/20207301001

Abuselidze, G., and Slobodianyk, A. (2021). Pandeconomic Crisis and Its Impact on Small Open Econ-omies: A Case Study of COVID-19. International Scientific Conference Energy Management of Municipal Facilities and Sustainable Energy Technologies EMMFT 2019. Advances in Intelligent Systems and Computing. 1258, 718-728. Springer, Cham. DOI: https://doi.org/10.1007/978-3-030-57450-5_61

Agostino, M., and Trivieri, F. (2008). Banking competition and SMEs bank financing. Evidence from the Italian provinces. Journal of Industry, Competition and Trade. 8(1), 33-53. DOI: https://doi.org/10.1007/s10842-007-0005-y

Agostino, M., and Trivieri, F. (2010). Is banking competition beneficial to SMEs? An empirical study based on Italian data. Small Business Economics. 35(3), 335-355. DOI: https://doi.org/10.1007/s11187-0089154-6

Agostino, M., Gagliardi, F., and Trivieri, F. (2012). Bank competition, lending relationships and firm default risk: An investigation of Italian SMEs. International Small Business Journal. 30(8), 907-943. DOI: https://doi.org/10.1177/0266242611416681

Andrieş, A. M., and Căpraru, B. (2014). The nexus between competition and efficiency: The European banking industries experience. International Business Review. 23(3), 566-579. DOI: https://doi.org/10.1016/j.ibusrev.2013.09.004

Bank of Georgia, (2019). ATMs and branches. Retrieved from: https://bankofgeorgia.ge/retail/ge/branchesand-atms

Bikker, J. A., and Bos, J. W. (2005). Competition and efficiency in banking: international comparisons. Economic and Financial Modelling. 12(3), 103-148.

Boyd, J. H., and De Nicolo, G. (2005). The theory of bank risk taking and competition revisited. The Journal of finance. 60(3), 1329-1343. DOI: https://doi.org/10.1111/j.1540-6261.2005.00763.x

Beck, T., De Jonghe, O., and Schepens, G. (2013). Bank competition and stability: Cross-country heterogeneity. Journal of financial Intermediation. 22(2), 218-244. DOI: https://doi.org/10.1016/j.jfi.2012.07.001

Berger, A. N., Klapper, L. F., and Turk-Ariss, R. (2009). Bank Competition and Financial Stability. J Financ Serv Res. 35, 99-118. DOI: https://doi.org/10.1007/s10693-008-0050-7

Carletti, E., and Hartmann, P. (2003). Competition and Financial Stability: What's Special about Banking?, Monetary History, Exchange Rates and Financial Markets: Essays in Honour of Charles Goodhart. ed P Mizen. DOI: https://doi.org/10.4337/9781781950784.00021 
Canhoto, A. (2004). Portuguese banking: A structural model of competition in the deposits market. Review of financial economics. 13(1-2), 41-63. DOI: https://doi.org/10.1016/j.rfe.2003.07.002

Casu, B., and Girardone, C. (2006). Bank competition, concentration and efficiency in the single European market. The Manchester School. 74(4), 441-468. DOI: https://doi.org/10.1111/j.14679957.2006.00503.x

Chalikias, M., Lalou, P., Skordoulis, M., Papadopoulos, P., and Fatouros, S. (2020). Bank oligopoly competition analysis using a differential equations model. International Journal of Operational Research. 38(1), $137-$ 145. DOI: https://doi.org/10.1504/IJOR.2020.106364

Claessens, S., and Laeven, L. (2004). What Drives Bank Competition? Some International Evidence. Journal of Money, Credit \& Banking. 36(3), S563. DOI: https://doi.org/10.1596/1813-9450-3113

Coccorese, P. (2008). Bank competition and regional differences. Economics Letters. 101(1), 13-16. DOI: https://doi.org/10.1016/j.econlet.2008.03.019

Dash, S., Pradhan, R. P., Maradana, R. P., and et al. (2020). Impact of banking sector development on insurance market-growth nexus: the study of Eurozone countries. Empirica. 47, 205-243. DOI: https://doi.org/10.1007/s10663-018-9412-z

Delis, M. D., and Papanikolaou, N. I. (2009). Determinants of bank efficiency: evidence from a semiparametric methodology. Managerial Finance. 35(3), 260-275. DOI: https://doi.org/10.1108/03074350910931771

De-Ramon, S., Francis, W., and Straughan, M. (2018). Bank competition and stability in the United Kingdom. (Bank of England), 748. DOI: https://doi.org/10.2139/ssrn.3226827

Eyubov, T. V. (2012). Current Issues of Improving Stability of the Banking System, Science and Business: Development Ways. 6(12), 98-102.

Fu, X. M., Lin, Y. R., and Molyneux, P. (2014). Bank competition and financial stability in Asia Pacific. Journal of Banking \& Finance. 38, 64-77. DOI: https://doi.org/10.1016/j.jbankfin.2013.09.012

Gischer, H., and Stiele, M. (2009). Competition Tests with a Non-Structural Model: the Panzar-Rosse Method Applied to Germany's Savings Banks. German Economic Review. 10(1), 50-70. DOI: https://doi.org/10.1111/j.1468-0475.2008.00441.x

Hamza, R. A. (2011). Validation Panzar-Rosse Model in determining the structural characteristics of Tunisian banking industry. Journal of Economics and International Finance. 3(5), 259-268.

Jayakumar, M., Pradhan, R. P., Dash, S., Maradana, R. P., and Gaurav, K. (2018). Banking competition, banking stability, and economic growth: Are feedback effects at work?. Journal of Economics and Business. 96, 15-41. DOI: https://doi.org/10.1016/j.jeconbus.2017.12.004

Kanas, A., Hassan Al-Tamimi, H. A., Albaity, M., and Mallek, R. S. (2019). Bank competition, stability, and intervention quality. International Journal of Finance \& Economics. 24(1), 568-587. DOI: https://doi.org/10.1002/ijfe.1680

Liberty Bank, (2019). ATMs and branches. Retrieved from: https://www.libertybank.ge/ka/chvenshesakheb/kompaniis-shesakheb/chveni-qseli

Liberty Bank, (2019). Term deposits. Retrieved https://www.libertybank.ge/ka/produqtebi/chemtvis/anabrebi-da-sertipikatebi/vadiani

Linda, R. (1976). Methodology of concentration analysis applied to the study of industries and markets. Retrieved from: http://aei.pitt.edu/33888/1/A597.pdf

Lerner, A. P. (1934). The concept of monopoly and the measurement of monopoly power. Review of Economic Studies. 1(3), 157-175. DOI: https://doi.org/10.2307/2967480

Leroy, A. (2019). Banking competition, financial dependence and productivity growth in Europe. International Economics. 159, 1-17. DOI: https://doi.org/10.1016/j.inteco.2016.01.001

Maradana, R. P., Pradhan, R. P., Dash, S., Gaurav, K., Jayakumar, M., and Chatterjee, D. (2017). Does innovation promote economic growth? Evidence from European countries, Journal of Innovation and Entrepreneurship. 6(1), 1. DOI: https://doi.org/10.1186/s13731-016-0061-9

Mandic, K., Delibasic, B., Knezevic, S., and Benkovic, S. (2014). Analysis of the financial parameters of Serbian banks through the application of the fuzzy AHP and TOPSIS methods. Economic Modelling. 43, 3037. DOI: https://doi.org/10.1016/j.econmod.2014.07.036

Marius, A. A., and Căpraru, B. (2012). Competition and efficiency in EU27 banking systems. Baltic Journal of Economics. 12(1), 41-60. DOI: https://doi.org/10.1080/1406099X.2012.10840510

Marcus, A. J. (1984). Deregulation and Bank Financial Policy. Journal of Banking \& Finance. 8(4), 557-565. DOI: https://doi.org/10.1016/S0378-4266(84)80046-1 
Memić, D. (2015). Banking competition and efficiency: empirical analysis on the Bosnia and Herzegovina using panzar-rosse model. Business Systems Research Journal. 6(1), 72-92. DOI: https://doi.org/10.1515/bsrj2015-0005

Montes, C. P. (2014). The effect on competition of banking sector consolidation following the financial crisis of 2008. Journal of Banking \& Finance. 43, 124-136. DOI: https://doi.org/10.1016/j.jbankfin.2014.03.004

National bank of Georgia, (2018). Financial stability 2006-2017 years datas. Retrieved from: https://www.nbg.gov.ge/index.php?m=404

National Bank of Georgia, (2019a). Annual report 2018. Retrieved from: https://www.nbg.gov.ge/uploads/publications/annualreport/2019/annual_2018.pdf

National Bank of Georgia, (2019b). New regulations. Retrieved from: https://www.nbg.gov.ge/index.php? $\mathrm{m}=340$ \&newsid $=3545$

Nitsche, R., and Heidhues, P. (2006). Study on methods to analyse the impact of State aid on competition. 244. (Directorate General Economic and Financial Affairs (DG ECFIN), European Commission).

Oliver, H., and Hirschman, A. (1946). National Power and the Structure of Foreign Trade. Southern Economic Journal. 12(3), 304. DOI: https://doi.org/10.2307/1052282

Ou, C. M., and Tan, Y. J. (2011). Multi-perspective Studies on Competition Degree of Chinese Banking Industry: Empirical Analysis Based on Panzar-Rosse Method, Systems engineering, 2 (006).

Rezitis, A. N. (2010). Evaluating the state of competition of the Greek banking industry. Journal of International Financial Markets, Institutions and Money. 20(1), 68-90. DOI: https://doi.org/10.1016/j.intfin.2009.10.001

Ruckes, M. (2004). Bank competition and credit standards. Review of Financial Studies. 17(4), 1073-1102. DOI: https://doi.org/10.1093/rfs/hhh011

Ruzmatovich, K. M. (2020). The problems of assessing the competition of commercial banks through the index lerner. ACADEMICLA: An International Multidisciplinary Research Journal. 10(3), 142-150. DOI: https://doi.org/10.5958/2249-7137.2020.00063.4

Savel'eva, N., Prokopenko, L., Zueva, N., Kuklin, A., and Yanov, I. (2017). Method of determining the efficiency of price and non-price competition in service sector. MATEC Web of Conferences. 106, 08084. DOI: https://doi.org/10.1051/matecconf/201710608084

Schaeck, K., Cihak, M., and Wolfe, S. (2009). Are competitive banking systems more stable?. Journal of Money, Credit and Banking. 41(4), 711-734. DOI: https://doi.org/10.1111/j.1538-4616.2009.00228.x

Schaeck, K., and Cihak, M. (2012). Banking competition and capital ratios. European Financial Management. 18(5), 836-866. DOI: https://doi.org/10.1111/j.1468-036X.2010.00551.x

Schaeck, K., and Cihak, M. (2014). Competition, Efficiency, and Stability in Banking. Financial Management. 43(1), 215-241. DOI: https://doi.org/10.1111/fima.12010

Serey, J., Soto, I., Quezada, L., Carrasco, R., and Sun, L. (2015). Development of a Competition Model for Selecting Information Security Methods, In LISS 2013. (Springer, Berlin, Heidelberg) 1287-1292. DOI: https://doi.org/10.1007/978-3-642-40660-7_193

Shair, F., Sun, N., Shaorong, S., Atta, F., and Hussain, M. (2019). Impacts of risk and competition on the profitability of banks: Empirical evidence from Pakistan. PLOS ONE. 14(11), e0224378. DOI: https://doi.org/10.1371/journal.pone.0224378

Staikouras, C. K., and Koutsomanoli-Fillipaki, A. (2006). Competition and concentration in the new European banking landscape. European Financial Management. 12(3), 443-482. DOI: https://doi.org/10.1111/j.1354-7798.2006.00327.x

Stazhkova, P., Kotcofana, T., and Protasov, A. (2017). Concentration indices in analysis of competitive environment: case of Russian banking sector. CBU International Conference Proceedings. 5, 458-464. DOI: https://doi.org/10.12955/cbup.v5.966

Sufian, F. (2011). The nexus between financial sector consolidation, competition and efficiency: empirical evidence from the malaysian banking sector. IMA Journal of Management Mathematics. 22(4), 419-444. DOI: https://doi.org/10.1093/imaman/dpr015

Tabak, B. M., Fazio, D. M., and Cajueiro, D. O. (2012). The relationship between banking market competition and risk-taking: Do size and capitalization matter?. Journal of Banking \& Finance. 36(12), 3366-3381. DOI: https://doi.org/10.1016/j.jbankfin.2012.07.022 
Tan, Y. (2016). The impacts of risk and competition on bank profitability in China. Journal of International Financial Markets, Institutions and Money. 40, 85-110. DOI: https://doi.org/10.1016/j.intfin.2015.09.003

Tan, Y. (2017). The impacts of competition and shadow banking on profitability: Evidence from the Chinese banking industry. The North American Journal of Economics and Finance. 42, 89-106. DOI: https://doi.org/10.1016/j.najef.2017.07.007

Tan, Y., Floros, C., and Anchor, J. (2017). The profitability of Chinese banks: impacts of risk, competition and efficiency. Review of Accounting and Finance. 16(1), 86-105. DOI: https://doi.org/10.1108/RAF-052015-0072

TBC Bank, (2019). ATMs and branches. Retrieved from: http://www.tbcbank.ge/web/ka/web/guest/branches-and-atms

TBC Bank, (2019). Entered the Uzbek market. Retrieved from: https://www.tbcbank.uz/?lang=en

TBC Bank, (2018). Is the shareholder of Azerbaijan Bank. Retrieved from: https://www.nikoil.az/en/news/206/nikoil-bank-enters-into-strategic-partnership-agreementwith-tbc-bank.

Tera Bank, (2019). Consumer loan and mortgage loan. Retrieved from: https://www.terabank.ge/ge/retail/loans/consumer-loans

Titko, J., Kozlovskis, K., and Kaliyeva, G. (2015). Competition-stability relationship in the banking sector. Systemics, Cybernetics and Informatics. 13(2), 25-31.

VTB Bank, (2019). ATM-s and branches. Retrieved from: https://vtb.ge/ge/about-thebank $/ \sim / \mathrm{m} / \mathrm{u} / \mathrm{ck} /$ ATMs\%20and\%20branches/GEO-24.04.pdf

Wang, T. (2015). Competition and increasing returns to scale: A model of bank size. The Economic Journal. 125(585), 989-1014. DOI: https://doi.org/10.1111/ecoj.12104

Weinstock, D. S. (1982). Using the Herfindahl Index to measure concentration. Antitrust Bull. 27, 285.

Werden, G. J. (1998). Using the Herfindahl-Hirschman index. Applied Industrial Economics. 368-374. DOI: https://doi.org/10.1017/cbo9780511522048.021

Yildirim, H. S., and Philippatos, G. C. (2007). Competition and contestability in Central and Eastern European banking markets. Managerial Finance. 33(3), 195-209. DOI: https://doi.org/10.1108/03074350710718275

Zigraiova, D., and Havranek, T. (2016). Bank competition and financial stability: Much ado about nothing?, Journal of Economic Surveys. 30(5), 944-981. DOI: https://doi.org/10.1111/joes.12131 